\title{
Erratum: Toro, C. et al. On the Detection of Spectral Emissions of Iron Oxides in Combustion Experiments of Pyrite Concentrates. Sensors 2020, 20, 1284
}

\author{
Carlos Toro ${ }^{1,2, *}$, Sergio Torres ${ }^{3}{ }^{(0)}$, Víctor Parra ${ }^{2}{ }^{(D}$, Rodrigo Fuentes ${ }^{4}$, Rosario Castillo ${ }^{5}{ }^{(}$, \\ Walter Díaz $^{2}(\mathbb{D})$, Gonzalo Reyes ${ }^{2}$, Eduardo Balladares ${ }^{2}(\mathbb{D})$ and Roberto Parra ${ }^{2}$ \\ 1 Dirección de Investigación, Universidad Tecnológica de Chile INACAP, Avenida el Condor 720, \\ Ciudad Empresarial, Huechuraba, Santiago RM858000, Chile \\ 2 Metallurgical Engineering Department, University of Concepción, Concepción CCP4070386, Chile; \\ vparras@udec.cl (V.P.); walterdiaz@udec.cl (W.D.); gonzaloreyes@udec.cl (G.R.); eballada@udec.cl (E.B.); \\ rparra@udec.cl (R.P.) \\ 3 Electrical Engineering Department, University of Concepción, Concepción CCP4070386, Chile; \\ sertorre@udec.cl \\ 4 Department of Analytical and Inorganic Chemistry, Faculty of Chemical Sciences, University of Concepción, \\ Concepción CCP4070386, Chile; rodrigoal@udec.cl \\ 5 Department of Instrumental Analysis, Faculty of Pharmacy \& Biotechnology Center, \\ University of Concepción, Concepción CCP4070386, Chile; rosariocastillo@udec.cl \\ * Correspondence: ctoron@inacap.cl; Tel.: +56-9-97910729
}

Received: 16 October 2020; Accepted: 26 October 2020; Published: 28 October 2020

The authors wish to make the following corrections to this paper [1]: we have found a typing error in the caption of Figure 9 (page 12) $-T_{\mathrm{S}}$ should have a value of $2220.3 \mathrm{~K}$, not $220.3 \mathrm{~K}$.

The correct caption of Figure 9 is

Figure 9. Non-linear curve fitting results for a spectrum from combustion of PyE sample, RMSE $($ root mean square error $)=0.4393, \theta_{0}=0.0249, T_{\mathrm{s}}=2220.3 \mathrm{~K}, \theta_{1}\left(\right.$ related to $\mathbf{I}_{1}$ or $\left.\mathrm{Na}\right)=3.4583$, $\theta_{2}\left(\right.$ related to $\mathbf{I}_{2}$ or $\left.\mathrm{Na}\right)=15.7373, \theta_{3}\left(\right.$ related to $\mathbf{I}_{3}$ or $\left.\mathrm{FeO}\right)=6.2484, \theta_{4}\left(\right.$ related to $\mathbf{I}_{4}$ or $\left.\mathrm{Fe}_{3} \mathrm{O}_{4}\right)=7.3093$ and $\theta_{5}$ (related to an offset) $=9.6 \times 10^{-8}$.

This change has no material impact on the conclusions of our paper. The authors would like to apologize for any inconvenience caused to the readers by this change.

\section{Reference}

1. Toro, C.; Torres, S.; Parra, V.; Fuentes, R.; Castillo, R.; Diaz, W.; Reyes, G.; Balladares, E.; Parra, R. On the Detection of Spectral Emissions of Iron Oxides in Combustion Experiments of Pyrite Concentrates. Sensors 2020, 20, 1284. [CrossRef]

Publisher's Note: MDPI stays neutral with regard to jurisdictional claims in published maps and institutional affiliations.

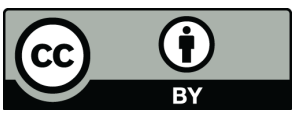

(C) 2020 by the authors. Licensee MDPI, Basel, Switzerland. This article is an open access article distributed under the terms and conditions of the Creative Commons Attribution (CC BY) license (http://creativecommons.org/licenses/by/4.0/). 